Review

\title{
Food-Grade Encapsulation Systems for (-)-Epigallocatechin Gallate
}

\author{
Meng Shi ${ }^{1}$, Yun-Long Shi ${ }^{1}$, Xu-Min Li ${ }^{1}$, Rui Yang ${ }^{1}$, Zhuo-Yu Cai ${ }^{1}$, Qing-Sheng Li ${ }^{1}$, \\ Shi-Cheng Ma ${ }^{2}$, Jian-Hui Ye ${ }^{1}$, Jian-Liang Lu ${ }^{1}$, Yue-Rong Liang ${ }^{1, *}$ and Xin-Qiang Zheng ${ }^{1, *}$ \\ 1 Tea Research Institute, Zhejiang University, Hangzhou 310058, China; 11616052@zju.edu.cn (M.S.); \\ 11516051@zju.edu.cn (Y.-L.S.); 21616096@zju.edu.cn (X.-M.L.); 21616106@zju.edu.cn (R.Y.); \\ 21716160@zju.edu.cn (Z.-Y.C.); qsli@zju.edu.cn (Q.-S.L.); jianhuiye@zju.edu.cn (J.-H.Y.); \\ jllu@zju.edu.cn (J.-L.L.) \\ 2 Liupao Tea Academy, Wuzhou 543003, China; zjumasc@aliyun.com \\ * Correspondence: yrliang@zju.edu.cn (Y.-R.L.); xqzheng@zju.edu.cn (X.-Q.Z.); \\ Tel.: +86-571-8898-2704 (Y.-R.L.); +86-571-8898-2704(X.-Q.Z.)
}

Received: 2 February 2018; Accepted: 15 February 2018; Published: 17 February 2018

\begin{abstract}
Epigallocatechin gallate (EGCG) has attracted significant research interest due to its health-promoting effects such as antioxidation, anti-inflammation and anti-cancer activities. However, its instability and poor bioavailability have largely limited its efficacy and application. Food-grade materials such as proteins, carbohydrates and lipids show biodegradability, biocompatibility and biofunctionality properties. Food-grade encapsulation systems are usually used to improve the bioavailability of EGCG. In the present paper, we provide an overview of materials and techniques used in encapsulating EGCG, in which the adsorption mechanisms of food-grade systems during in vitro digestion are reviewed. Moreover, the potential challenges and future work using food-grade encapsulates for delivering EGCG are also discussed.
\end{abstract}

Keywords: food; proteins; carbohydrates; lipids; EGCG; in vitro digestion

\section{Introduction}

Tea (Camellia sinensis) is the most widely consumed beverage in the world after water. A variety of bioactive ingredients including catechins in tea possess numerous health benefits such as antioxidant, anticancer, antidiabetic, antihyperglycemic, and UV-shielding effects [1-7]. Tea catechins are a group of bioactive polyphenols present in tea leaves, mainly comprising eight kinds of catechins, among which EGCG is the most abundant and shows the strongest bioactivity, making it an excellent candidate for application in drugs and functional food development [8]. However, the bioavailability of EGCG is relatively poor because of its instability and low permeability under the neutral or alkaline conditions of the gastrointestinal (GI) tract and also its active efflux effect $[9,10]$. Therefore, improving the digestive adsorption of EGCG and inhibiting its active efflux are considered to be an appropriate way to increase the bioavailability of EGCG to allow its nutritional functions to be enjoyed.

In the medical and functional food field, numerous encapsulation systems are available for the controlled delivery of bioactives to improve their bioavailability [11]. Food grade materials are generally abundant resources with advantages of biodegradability, biocompatibility, functionality and low-cost, which show great potential for protectively delivering bioactive compounds through human GI tract to target tissues [12,13]. There is considerable interest in improving the flavor and increasing the bioavailability of EGCG using food-grade encapsulation systems. The present review aims at combining the encapsulation technologies and delivery efficiencies insights to highlight the fabrication methods and essential parameters that should be taken into consideration when developing 
encapsulates for protecting EGCG. Furthermore, some challenges and future research directions are also discussed in this review.

\section{EGCG in Tea}

EGCG is a key family member of catechins originating from tea. The content of EGCG is the highest among the catechins in green tea leaves. Structurally, EGCG is comprised of two aromatic rings conjugated by a three-carbon bridge, namely a C6-C3-C6 structure, with hydroxyl groups at carbons 3', $4^{\prime}, 5^{\prime}$ of the B ring and a gallate moiety esterifying carbon three of the $C$ ring [14,15] (Figure 1). EGCG is rich in phenolic hydroxyl groups, which lead it possess health-beneficial activities. A number of in vivo and in vitro studies have been performed to show that EGCG has beneficial anti-oxidative, anti-inflammatory and anticarcinogenic properties [16-21].

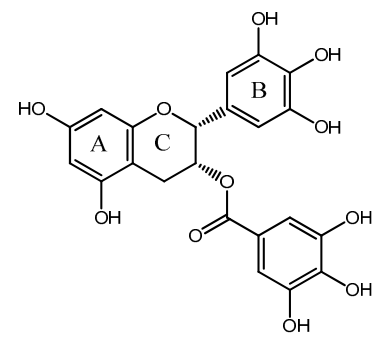

Figure 1. The chemical structure of EGCG.

However, the production or preservation stability of EGCG is poor, which is one of the primary limitations of EGCG applications. There are many factors influencing the stability of EGCG, such as light, temperature, pH, oxygen, EGCG concentration, and also the level of oxidants [22-26]. Auto-oxidation and epimerization are two significant reactions causing the instability of EGCG and leading to the partial loss of its health-promoting effects [27]. EGCG is a pH and temperature sensitive compound and at low concentration (such as 20-100 $\mathrm{MM}$ ), it is apt to be oxidized under conditions of lower temperature $\left(<44^{\circ} \mathrm{C}\right)$, neutral and alkaline $\mathrm{pH}$ conditions. Meanwhile, when EGCG is at a high concentration ( $\mathrm{mM}$ level or higher) and under higher temperature $\left(>44^{\circ} \mathrm{C}\right)$ and acidic $(\mathrm{pH} 2-5.5)$ conditions, it is apt to be epimerized to its isomer gallocatechin gallate (GCG) [9,27-29]. EGCG $(300 \mathrm{mg} / \mathrm{L})$ remains stable in solution at $\mathrm{pH}$ of $3-6$ and $25^{\circ} \mathrm{C}$ for $24 \mathrm{~h}$, but $25 \%$ and $83 \%$ of it is lost if kept in pH 7 citrate buffer solution for $24 \mathrm{~h}$ at $4{ }^{\circ} \mathrm{C}$ and $25^{\circ} \mathrm{C}$, respectively [25]. When EGCG (500 $\left.\mu \mathrm{M}\right)$ was kept at $60{ }^{\circ} \mathrm{C}$ and $90{ }^{\circ} \mathrm{C}$ for $8 \mathrm{~h}$, respectively, 3.2\% and $27.4 \%$ of the EGCG was epimerized into GCG [26]. The EGCG epimerization product GCG possesses similar health functions to EGCG, with no toxic effects, however, the oxidation of EGCG is usually accompanied with brown coloration and creaming, in which higher molecular weight compounds are formed through polymerization [26,27].

Moreover, when consumed EGCG is exposed to oral administration systems with acidity ranging from $\mathrm{pH} 1.5$ in the stomach up to $\mathrm{pH} 8.5$ in the intestine, where the main adsorption occurs [9]. It has been reported that the alkaline environment of intestinal digestion is one of the main reasons leading to its poor bioavailability [30-33]. In an in vitro simulated GF digestion model, EGCG recovery was between $6.1 \%$ to $12.1 \%$ under various tested conditions [31,34,35]. However, a high stability of EGCG was observed by adding ascorbic acid, with 29.6\% loss [36]. EGCG is hydrophilic, and no specific receptors have been found on the surface of small intestinal epithelial cells to carry EGCG into cells. Generally, an apparent permeability coefficient $\left(P_{\text {app }}\right)>1 \times 10^{-6} \mathrm{~cm} / \mathrm{s}$ means high permeation, while $\mathrm{P}_{\mathrm{app}}<1 \times 10^{-7}$ stands for low permeation. The $\mathrm{P}_{\mathrm{app}}$ for EGCG is as low as $0.8 \times 10^{-7}$ to $3.5 \times 10^{-7} \mathrm{~cm} / \mathrm{s}$ [37-39]. EGCG is transported across the epithelium through passive diffusion, including paracellular and transcellular diffusion [40]. After absorption, EGCG can be extruded back into the lumen by active efflux. This efflux process is associated with efflux transporters including ATP-binding cassette transporters families such as p-glycoprotein (P-gps), multidrug resistance-associated proteins (MRPs), and breast cancer resistance protein (BCRP), which 
are distributed in the surface of the intestinal epithelial cell [41]. Studies have suggested that EGCG and its metabolites are pumped out by MRPs [37,40,42]. The efflux effects were inhibited in the presence of selective MRP inhibitors (indomethacin, probenecid, MK571), resulting in increasing $P_{\text {app }}$ values, while the cellular uptake of EGCG in the presence of Pgp inhibitors (cyclosporine A, vinblastine, GF120918, indomethacin, probenecid) was not changed [37,40,42]. These results suggest that EGCG and its methylated metabolites are substrates of MRP1 and MRP2, but not a substrate of Pgp. It was this sensitivity and poor stability, passive diffusion and active efflux of EGCG in the GI tract that cause its low adsorption and bioavailability. Therefore, it is of great importance to develop new materials as edible EGCG biological carriers to improve its stability and bioavailability.

\section{Food-Grade Encapsulation System}

\subsection{Proteins for EGCG Encapsulation}

Food-grade proteins have been commonly used as hydrophilic emulsifiers to form oil-in-water emulsions. They are natural nutritional materials and show excellent aqueous solubility, emulsifying and film formation properties. Proteins, such as sodium caseinate, gelatin, whey protein, and zein proteins, are commonly used as wall materials for many polyphenols like EGCG. All proteins are amphiphilic and show different spatial structures and physical and chemical properties under various external conditions. The functional properties of the proteins may be modified or improved through appropriate processes [43], which extend their application for encapsulation. Crosslinking between proteins and EGCG could enhance the encapsulation. In recent years, proteins and peptides with superior properties were broadly used as encapsulation shell materials in the food industry. An extensive list of food-grade proteins used for encapsulating EGCG is given in Table 1.

Protein encapsulation usually occurs starting from emulsions. Milk proteins are effective encapsulating materials. Casein and whey are the major milk proteins. Milk proteins are frequently used in combination with polysaccharide and lipids. Sodium caseinate $(0.5 \%)$ and soybean oil $(10 \%)$ has been used in the formulation of nano-sized (230-250 nm) oil-in-water emulsions with EGCG at concentrations up to $6 \mathrm{mg} / \mathrm{mL}$ [44]. Sodium caseinate adsorbed at the oil-water interface can associate to high concentrations of EGCG. More than $90 \%$ of the EGCG was loaded at the interface when EGCG concentration was up to $2 \mathrm{mg} / \mathrm{mL}$, and about 70\% EGCG was adsorbed when the EGCG concentration was up to $5 \mathrm{mg} / \mathrm{mL}$ [44]. However, acidic conditions destabilized the emulsions, while addition of high methoxyl pectin (HMP) could improve its stability at low $\mathrm{pH}$ [45]. Sodium caseinate-stabilized emulsions can be employed as a platform for EGCG delivery, during which an emulsion of $240 \mathrm{~nm}$ size was obtained with a formulation of $0.35 \%$ sodium caseinate, $20 \%$ soybean oil, $0.45 \%$ HMP at EGCG levels between $0-6 \mathrm{mg} / \mathrm{mL}$ [46]. An in vitro digestion showed that the presence of EGCG reduced the extent of free fatty acid release during the duodenal phase, but sodium caseinate was fully hydrolyzed [46].

Whey protein isolate and bacterial cellulose were used to encapsulate hydrophilic or lipophilized EGCG using emulsion electrospraying with encapsulation efficiencies (EEs) ranging from $56 \%$ to $97 \%$ and particle sizes from 253 to $3226 \mathrm{~nm}$ [47]. The stability of EGCG in the particles during storage was influenced by the relative humidity $(\mathrm{RH}), \mathrm{pH}$ and temperature. Low $\mathrm{RH}(26-53 \%)$ and neutral or alkaline $\mathrm{pH}(6-9)$ conditions were beneficial to protecting EGCG in the particles [47]. The non-capsulated free EGCG was completely degraded after storage at $37^{\circ} \mathrm{C}$ for 7 days or at $60^{\circ} \mathrm{C}$ for 4 days. The emulsion was completely degraded after storage at $37^{\circ} \mathrm{C}$ for 25 days or at $60^{\circ} \mathrm{C}$ for 20 days [47]. $\beta$-Lactoglobulin ( $\beta$-LG) is the most abundant whey protein and wildly used as a natural delivery protein for bioactive components. $\beta$-LG $(0.4 \%)$, L-carrageenan $(0.6 \%)$ and canola oil $(5 \%)$ stabilized oil/water $(\mathrm{O} / \mathrm{W})$ emulsion $(\sim 400 \mathrm{~nm})$ was more stable with lower EGCG concentration $(<0.5 \%)$ and the emulsion droplet size showed negligible changes within 14 days [48]. $\beta$-LG combined with chitosan can form smaller nanoparticles of $193.8 \mathrm{~nm}$ size to carry EGCG [49]. Recently, $\beta$-LG-chlorogenic acid complex showed better antioxidant activities than using $\beta$-LG alone, and EGCG loaded $\beta$-LG-chlorogenic acid nanoparticles (105- $110 \mathrm{~nm}$ ) better EEs ranging from 71.8 to $73.5 \%$ [50]. 
Table 1. Overview of studies on the effect of protein based encapsulation on EGCG.

\begin{tabular}{|c|c|c|c|c|c|c|c|}
\hline Wall Material & ET & APS (nm) & EE (\%) & ZP & PI & Activity & Reference \\
\hline Sodium caseinate & Emulsion & $230 \sim 250$ & / & $-41 \sim-43$ & I & I & Sabouri et al., 2015 [44] \\
\hline Sodium caseinate Pectin & Emulsion & 240 & / & / & / & $\begin{array}{l}\text { No inhibition of proteolytic; Reduce free } \\
\text { fatty acid release }\end{array}$ & Sabouri et al., 2017 [46] \\
\hline $\begin{array}{l}\text { Whey protein; } \\
\text { Bacterial cellulose }\end{array}$ & Emulsion; electrospray & $253 \sim 3226$ & $56 \sim 97$ & / & $0.5 \sim 2.9$ & $\begin{array}{l}\text { Protection against moisture, heating and } \\
\text { dissolution during storage }\end{array}$ & Paximada et al., 2017 [47] \\
\hline$\beta$-LG; L-carrageenan & Emulsion & $\sim 400$ & / & / & I & Enhanced in vitro anticancer activity & Ru et al., 2010 [48] \\
\hline$\beta$-LG; Chitosan & Ionic gelation & $100 \sim 500$ & $54.2 \sim 60.7$ & $10 \sim 35$ & 0.13 & Controlled release of EGCG & Liang et al., 2016 [49] \\
\hline$\beta$-LG-chlorogenic acid & $\begin{array}{l}\text { Covalent grafting; } \\
\text { freeze dry }\end{array}$ & $105 \sim 110$ & $71.8 \sim 73.5$ & $-44 \sim-48$ & / & $\begin{array}{l}\text { Protection against degradation or } \\
\text { oxidation }\end{array}$ & Fan et al., 2017 [50] \\
\hline Gelatin & Self-assembly & $50 \sim 300$ & / & / & / & $\begin{array}{l}\text { Retain antioxidant activity; High loading } \\
(30 \%, w / w)\end{array}$ & Shutava et al., $2009[51,52]$ \\
\hline Gelatin & Electrospray & 470 & 96 & / & / & Increase in vitro antioxidant activity & $\begin{array}{l}\text { Gomez-Mascaraque et al., } \\
2015 \text { [53] }\end{array}$ \\
\hline Gelatin; $\gamma$-PGA & ionic gelation & / & $62.7 \sim 68.7$ & / & / & Sustained release of EGCG & Garcia et al., 2014 [54] \\
\hline Gelatin & Electrospray & $\sim 5000$ & 95 & / & / & $\begin{array}{l}\text { Delay EGCG release and degradation; } \\
\text { Protection against oxidation }\end{array}$ & $\begin{array}{l}\text { Gomez-Mascaraque et al., } \\
2016 \text { [55] }\end{array}$ \\
\hline Zein; Sodium caseinate & Antisolvent; precipitation & $170 \sim 250$ & $37 \sim 46$ & $-30 \sim-42$ & $<0.15$ & Control EGCG release and fat digestion & Donsi et al., 2017 [56] \\
\hline Zein; Chitosan & $\begin{array}{l}\text { Vacuum evaporation; } \\
\text { freeze dry }\end{array}$ & $156 \sim 241$ & $61.4 \sim 80.7$ & $21.1 \sim 35.1$ & $0.09 \sim 0.23$ & Protection against oxidation & Liang et al., 2017 [57] \\
\hline Ferritin; Urea & Self-assembly & 12 & 17.6 & / & / & Improve EGCG stability & Yang et al., 2017 [58] \\
\hline
\end{tabular}

ET: encapsulation technique, EE: encapsulation efficiency, APS: average particle size, ZP: zeta potential; PI: polydispersity index; $\gamma$-PGA: $\gamma$-polyglutamic acid; /: no data. 
Besides milk proteins, other edible proteins are also used as wall materials for encapsulating EGCG. Gelatin shows remarkable gelation properties with different gel strength and chain length and is usually used to encapsulate gelatin/EGCG particles by a layer-by-layer assembly technique [51,52]. Food-grade gelatin EECG encapsulates were produced from the appropriate ingredients by electrospraying in dilute acetic acid, with high EGCG EE (96\%) while avoiding the use of high temperatures and toxic solvents [53]. Hydrogels prepared from gelatin and $\gamma$-polyglutamic acid ( $\gamma$-PGA) through ionic interaction presented sustained release of EGCG [54]. A comparative study on EGCG micro-hydrogels prepared using the biopolymers gelatin and chitosan showed that gelatin was more adequate as a wall material for the encapsulation of EGCG than chitosan, achieving higher EE (95 $\pm 6 \%$ ), being more effective in delaying EGCG release and degradation in aqueous solution and exhibiting 7-times higher bioaccessibility of the EGCG than chitosan after in vitro gastrointestinal digestion. The low bioaccessibility of EGCG in chitosan was due to the neutralization of the carbohydrate in the basic simulated salivary conditions, which precluded subsequent flavonoid release. Also, the gelatin micro-hydrogels hindered dimer formation during in vitro digestion, resulting in increased bioavailability [55].

Zein, as a water-insoluble plant protein from a renewable natural source, has been used to form EGCG colloidal particles with sodium caseinate as a stabilizer in sizes ranging from $170 \mathrm{~nm}$ to $250 \mathrm{~nm}$ by the anti-solvent precipitation technique [56]. Zein/chitosan nanoparticle fabrication via evaporation and freeze drying showed a controlled-release of EGCG and protection of EGCG from oxidation [57]. The fabrication of ferritin-EGCG co-assemblies induced by urea $(20 \mathrm{mM})$ enhanced the EGCG stability, with homogeneous state spheres being $12 \mathrm{~nm}$ in size and $17.6 \%$ in EE, in which the urea played an essential role in promoting the permeation of EGCG into the ferritin cage [58].

The techniques for encapsulating EGCG using food-grade proteins include emulsification, ionic gelation, freeze drying, electrospraying, self-assembly, layer-by-layer assembly, vacuum evaporation, precipitation and covalent grafting. The protein-encapsulated EGCG showed remarkably enhanced stability and bioavailability, and they can be considered multi-functional EGCG delivery systems.

\subsection{Carbohydrates for EGCG Microencapsulation}

Carbohydrates, including chitosan, cellulose polymers, starch-based materials, gum arabic and sodium alginate, are preferred as encapsulating matrices for many applications due to their good biocompatibility and biodegradability as well as non-toxicity. Their thermal and emulsification functional properties, are complex and it is necessary to choose the polymers properly and modifications such as starch modification are usually employed. Chitosan in particular is the most common encapsulation material for EGCG. Gum arabic and sodium alginate are by far the best wall materials for encapsulating hydrocolloids. Carbohydrates can stabilize formulations and provide barrier protection and controlled release of the bioactive compounds. Studies on encapsulating EGCG using carbohydrates are listed in Table 2.

When EGCG was incorporated into a gum arabic-maltodextrin matrix at a particle size $120 \mathrm{~nm}$ by homogenization and spray drying methods, the EE reached $85 \%$ and the antioxidant properties of EGCG were preserved [59]. By changing the proportion of food grade matrix and EGCG, the EE was increased as high as $96 \%$, with a zeta-potential of -36 [60]. Homogenization is a simple, efficient and environmentally friendly method that can produce small and stable particles. EGCG-loaded nanoparticles fabricated by alginate and chitosan by high-pressure homogenization resulted in higher DPPH radical scavenging activity [61]. EGCG on particles prepared by gas saturated solution drying (PGSS-drying) using octenylsuccinate starch (OSA-starch), soybean lecithin and $\beta$-glucan, three distinct natural origin carriers, showed enhanced storage capacity and antioxidant activity, among which $\beta$-glucan and soybean lecithin systems were confirmed to improve the intracellular activity of EGCG [62]. 
Table 2. Overview of studies on the effect of carbohydrates based encapsulation on EGCG.

\begin{tabular}{|c|c|c|c|c|c|c|c|}
\hline Wall Material & ET & APS (nm) & EE (\%) & $\mathrm{ZP}$ & PI & Activity & Reference \\
\hline Gum arabic-maltodextrin & $\begin{array}{l}\text { Homogenization; } \\
\text { spray dry }\end{array}$ & $40 \sim 400$ & 96 & -36 & 0.58 & Preserve EGCG antioxidant properties & Peres et al., 2011 [59] \\
\hline Gum arabic-maltodextrin & $\begin{array}{l}\text { Homogenization; } \\
\text { spray dry }\end{array}$ & 120 & 85 & -12.3 & 0.45 & $\begin{array}{l}\text { Retain EGCG inhibitory effects on } \\
\text { prostate cancer cells proliferative }\end{array}$ & Rocha et al., 2011 [60] \\
\hline Alginate; chitosan & Homogenization & 293 & 80.1 & +37.49 & / & Higher DPPH radical scavenge activity & Park et al., 2016 [61] \\
\hline OSA-starch & Precipitation; GSSD & 2000 & 80.5 & / & / & $\begin{array}{l}\text { Higher storage ability; Higher } \\
\text { antioxidant activity }\end{array}$ & Goncalves et al., 2016 [62] \\
\hline$\beta$-Glucan & Precipitation; GSSD & 20,900 & 77.4 & / & / & $\begin{array}{l}\text { Higher storage and antioxidant ability; } \\
\text { Improve EGCG intracellular activity }\end{array}$ & Goncalves et al., 2016 [62] \\
\hline Chitosan; polyaspartic acid & Self-assembly & 102.4 & 25 & +33.3 & 0.224 & $\begin{array}{l}\text { Improve the ability against rabbit } \\
\text { atherosclerosis }\end{array}$ & Hong et al., 2014 [63] \\
\hline $\begin{array}{l}\text { Amphiphilic chitosan; } \\
\text { dextran sulfate; cholesterol }\end{array}$ & Self-assembly & $64.5 \sim 189.8$ & $90.8 \sim 95.1$ & $+40.6 \sim+51.8$ & $0.323 \sim 0.422$ & $\begin{array}{l}\text { Sustaining release and protect EGCG from } \\
\text { degradation }\end{array}$ & Zou et al., 2015 [64] \\
\hline CPP; chitosan; gallic acid & $\begin{array}{l}\text { Self-assembly; } \\
\text { freeze dry }\end{array}$ & $\sim 300$ & $84 \sim 90$ & I & / & $\begin{array}{l}\text { Controlled release; Prevent degradation } \\
\text { and amplify anticancer against } \\
\text { caco-2 cells }\end{array}$ & Hu et al., 2015 [65] \\
\hline Bioactive peptides; CPP; chitosan & Ionic gelation & 143.7 & $70.5 \sim 81.7$ & 30.8 & $0.08 \sim 0.13$ & $\begin{array}{l}\text { Controlled release and increase cellular } \\
\text { antioxidant }\end{array}$ & Hu et al., 2013 [66] \\
\hline Chitosan; СРP & Ionic gelation & 150 & / & 32.2 & $0.05 \sim 0.14$ & Enhance EGCG intestinal permeability & Hu et al., 2012 [67] \\
\hline Chitosan; tripolyphosphate & Ionic gelation & 440 & / & 25 & / & $\begin{array}{l}\text { Enhance EGCG concentration in stomach, } \\
\text { jejunum and plasma of mice }\end{array}$ & Dube et al., 2010 [68] \\
\hline $\begin{array}{l}\text { CSH-SBE- } \beta-C D \\
\text { CMC; folate }\end{array}$ & $\begin{array}{l}\text { Ionic gelation } \\
\text { Ionic gelation }\end{array}$ & $\begin{array}{l}150 \sim 12,000 \\
401.3\end{array}$ & $\begin{array}{l}/ \\
75\end{array}$ & $\begin{array}{l}-5 \sim+30 \\
+36.6\end{array}$ & / & $\begin{array}{l}\text { Decrease antioxidant activity } \\
\text { Greater tumor inhibition effect }\end{array}$ & $\begin{array}{l}\text { Liu et al., } 2016 \text { [69] } \\
\text { Liang et al., } 2014 \text { [70] }\end{array}$ \\
\hline Caffeic acid; chitosan; CPP & Ionic gelation & 273.8 & 88.1 & +27.9 & 0.268 & $\begin{array}{l}\text { Controlled release; Prevent EGCG } \\
\text { degradation under neutral or alkaline }\end{array}$ & Hu et al., 2016 [71] \\
\hline Ferulic acid; chitosan; CPP & Ionic gelation & 251.3 & 90.4 & +25.7 & 0.386 & $\begin{array}{l}\text { Controlled release; Prevent EGCG } \\
\text { degradation under neutral or alkaline }\end{array}$ & Hu et al., 2016 [71] \\
\hline
\end{tabular}

hydrochloride; SBE- $\beta$-CD: sulfobutylether- $\beta$-cyclodextrin sodium; CPP:caseinophosphopeptide; CMC:carboxymethyl chitosan. 
Chitosan-based particles for encapsulating EGCG are commonly fabricated by two basic methods, i.e., self-assembly and ionic gelation. The self-assembly technique refers to the autonomous interaction between encapsulating agent and bioactive. EGCG-loaded nanoparticles prepared from chitosan and polyaspartic acid with a size of $102.4 \mathrm{~nm}$ effectively improved EGCG stability in body fluids and showed greater activity against rabbit atherosclerosis than free EGCG alone [63]. An encapsulation system using dextran sulfate-coated amphiphilic chitosan derivative-based nanoliposomes with a 64.5-189.8 nm size range via a layer-by-layer self-assembly technique exhibited excellent sustained release properties and protected EGCG from degradation during exposure to simulated intestinal fluid [64]. The EGCG nanoparticles composed of caseinophosphopeptide (CPP) and chitosan based on self-assembly and ionic gelation methods were mentioned in Table 2. Ionic gelation is also a widely used technique because it can be performed under mild conditions avoiding EGCG degradation. Among these studies, EGCG-loaded bioactive peptides chitosan particles prepared by ionic gelation presented smaller size $(\sim 150 \mathrm{~nm})$ and relatively lower EE $(70.5-81.7 \%)$ compared with those made by the self-assembly technique, whose size is around $300 \mathrm{~nm}$, with EEs ranging from $84 \%$ to 90\% [65-67]. Gallic acid grafted chitosan conjugates were found to show increased solubility in neutral and alkaline environments [65]. An in vitro digestion experiment showed EGCG controlled release or enhancement of intestinal permeability after encapsulation [65-67]. EGCG encapsulated in chitosan-tripolyphosphate nanoparticles with particle sizes of $440 \mathrm{~nm}$ enhanced the concentration of EGCG in the stomach and jejunum, resulting in an increased plasma exposure of EGCG [68].

Carboxymethyl chitosan (CMC) and chitosan hydrochloride (CSH) are different kinds of water-soluble chitosan with special structures containing carboxymethyl and amino groups. CMC and CSH form EGCG particles with larger sizes via ionic gelation $[69,70]$. Interestingly, EGCG loaded in CSH sulfobutylether- $\beta$-cyclodextrin sodium (CSH-SBE- $\beta$-CD) system displayed decreased antioxidant activity, which is considered to be related to the restriction of EGCG release and diffusion owing to the disappearance of the swollen rubbery matrix $[69,71]$. When chitosan was grafted with caffeic acid and ferulic acid and then assembled with CPP, the system showed high EE of EGCG and preventive effects against EGCG degradation under neutral or alkaline conditions [72].

\subsection{Lipids for EGCG Microencapsulation}

Lipids are often used as encapsulation material because of their crystallization, melt property and moisture barrier properties. There are three categories of lipids commonly used for encapsulation, i.e., hydrocarbon-rich substances, simple lipids, and lipid-derived substances. Lipids are often soluble in non-polar solvents and insoluble in water. However, liposomes can be made of a single type of phospholipids or by mixtures of different phospholipids, and are able to dissolve water-soluble and lipid-soluble molecules at the same time. For EGCG encapsulation, the lipid materials, encapsulation technique, and outcomes are shown in Table 3.

Liposome encapsulates of EGCG made using egg phosphatidylcholine (PC) and cholesterol via the organic solvent evaporation method, with average diameters of $378.2 \mathrm{~nm}$ and EE of $99 \%$, effectively protected EGCG against degradation during GI tract transit [73]. EGCG nanoliposome (EN) particles with $180 \mathrm{~nm}$ size and EE of $85.8 \%$ were obtained by the reverse-phase evaporation method using PC and cholesterol [74]. The EN was more stable during in vitro digestion and effectively enhanced the inhibitory effect on tumor cell viability at higher concentrations [74]. The EN prepared by the ethanol injection combined with dynamic high-pressure microfluidization, with an average size of $71.7 \mathrm{~nm}$ exhibited a high EE 92.1\%, and presented sustained release of EGCG. However, the zeta-potential was as low as -10.81 , showing the EN was unstable [75]. 
Table 3. Overview of studies on the effect of lipids based encapsulation on EGCG.

\begin{tabular}{|c|c|c|c|c|c|c|c|}
\hline Wall Material & ET & APS (nm) & EE (\%) & $\mathbf{Z P}$ & PI & Activity & Reference \\
\hline Egg; PC, cholesterol & $\begin{array}{l}\text { Organic solvent } \\
\text { evaporation }\end{array}$ & $104.6 \sim 378.2$ & $84.6 \sim 99$ & $-0.9 \sim-26.2$ & / & $\begin{array}{l}\text { Protection of EGCG against degradation; } \\
\text { Increase EGCG uptake by tumor }\end{array}$ & Fang et al., 2006 [73] \\
\hline PC; cholesterol & Reverse-phase evaporation & 180 & 85.79 & / & / & $\begin{array}{l}\text { More stable in vitro digestion; Modulate } \\
\text { the growth of Caco- } 2 \text { tumor cells }\end{array}$ & Luo et al., 2014 [74] \\
\hline Phospholipid, cholesterol & Ethanol injection; DHPM & 71.7 & 92.1 & -10.8 & 0.286 & Sustained release of EGCG & Zou et al., 2014 [75] \\
\hline Cholesterol & Ethanol injection & $\sim 60$ & 76.4 & / & 0.110 & $\begin{array}{l}\text { Increase in vitro digestion } \\
\text { antioxidant ability }\end{array}$ & Liang et al., 2016 [76] \\
\hline Soybean lecithin & $\begin{array}{l}\text { Precipitation gas saturated } \\
\text { solution drying }\end{array}$ & 8100 & 75.8 & I & / & $\begin{array}{l}\text { Higher storage ability and higher } \\
\text { antioxidant activity; Improve the } \\
\text { intracellular activity of EGCG }\end{array}$ & Goncalves et al., 2016 [59] \\
\hline Soy lecithin & Homogenization & $153 \sim 173$ & $53.1 \sim 70.9$ & $-42.4 \sim-46.1$ & / & $\begin{array}{l}\text { High retention in a low-fat hard cheese } \\
\text { system; High recovery from digestion }\end{array}$ & $\begin{array}{l}\text { Rashidinejad et al., 2014, } \\
2016[77,78]\end{array}$ \\
\hline $\begin{array}{l}\text { Soy lecithin glycerol } \\
\text { monostearate; stearic acid }\end{array}$ & $\begin{array}{l}\text { Emulsion-solvent } \\
\text { evaporation }\end{array}$ & $112.5 \sim 157.4$ & $67.2 \sim 89.5$ & $-30.1 \sim-37.2$ & $0.14 \sim 0.268$ & $\begin{array}{l}\text { Higher cy totoxicity against human breast } \\
\text { cancer and prostate cancer cells }\end{array}$ & $\begin{array}{l}\text { Radhakrishnan et al., } \\
2016 \text { [79] }\end{array}$ \\
\hline $\begin{array}{l}\text { Phospholipon } 90 \mathrm{G}, \\
\text { alginate, chitosan }\end{array}$ & $\begin{array}{l}\text { Proliposome method; } \\
\text { freeze dry }\end{array}$ & / & 97.5 & / & / & Higher stability in alkaline medium & Istenic et al., 2016 [80] \\
\hline NLC; Folate & $\begin{array}{l}\text { Homogenization; } \\
\text { ultrasonic freeze dry }\end{array}$ & 359 & 85 & -28 & 0.18 & $\begin{array}{l}\text { Controlled release of EGC; Storage } \\
\text { stability up to } 8 \text { weeks }\end{array}$ & Granja et al., 2017 [81] \\
\hline SLN & $\begin{array}{l}\text { Homogenization; } \\
\text { ultrasonic }\end{array}$ & 364 & 83 & -24 & 0.19 & $\begin{array}{l}\text { Stable for at least } 3 \text { months; High stability } \\
\text { and a slower release in vitro } \\
\text { digestion system }\end{array}$ & Frias et al., 2016 [82] \\
\hline NLC & $\begin{array}{l}\text { Homogenization; } \\
\text { ultrasonic }\end{array}$ & 300 & 90 & -28 & 0.15 & $\begin{array}{l}\text { Stable for at least } 3 \text { months; High stability } \\
\text { and a slower release of EGCG in vitro } \\
\text { digestion system }\end{array}$ & Frias et al., 2016 [82] \\
\hline
\end{tabular}

ET: encapsulation technique; EE: encapsulation efficiency; APS: average particle size; ZP:
carriers; SLN: solid lipid nanoparticle; DHPM: dynamic high-pressure microfluidization. 
EGCG in particles fabricated with cholesterol via ethanol injection exhibited stronger antioxidant ability than free EGCG [76]. EGCG-loaded niosomes had smaller particle size $(\sim 60 \mathrm{~nm})$ than EGCG EN, but their EE (76\%) was lower than that of EGCG EN [76]. EGCG microparticles formulated using soybean lecithin via a gas-saturated solution drying method improved the antioxidant activity and intracellular activity of EGCG [62]. EGCG in soy lecithin liposomes had high recovery rate after in vitro digestion [77,78]. EGCG liposomes fabricated using soy lecithin, glycerol monostearate and stearic acid by an emulsion-solvent evaporation method, with sizes ranging from 112.5 to $157.4 \mathrm{~nm}$ and EEs ranging from $67.2 \%$ to $89.5 \%$, improved the stability of the interface and prevented agglomeration [79]. EGCG liposomes subjected to further incorporation of the EGCG liposomes by proliposome method into alginate and chitosan microparticles protected EGCG against degradation at alkaline $\mathrm{pH}$ values [80].

Solid lipid nanoparticles (SLN) and nano-structured lipid carriers (NLC) prepared via a homogenization and ultrasonic assistance technique were used as biocompatible nanocarriers for delivering EGCG [81,82]. Because SLN had a solid-state core, it differed from NLC. Both SLN and NLC had large size particles (300-369 nm), high stability (from 8 weeks to 3 months) and great potential for the controlled release of EGCG in the GI tract [81,82]. An EGCG oral delivery system based on NLC functionalized with folic acid could stimulate the expression of folate receptors, resulting in improvement of the intestinal permeability of EGCG [81].

Above all, liposomes are considered to have a prosperous future for EGCG encapsulation, and SLN and NLC are looked at as innovative edible delivery systems for EGCG. The methods used to form liposomes include homogenization, ultrasonic and freeze drying. To improve the properties of EGCG liposomes, non-phospholipids, including cholesterol and fatty acids, were usually added during liposome preparation. The barriers to be overcome in this field include the chemical instability and degradation involving hydrolysis, oxidation, aggregation and fusion.

\subsection{Food Grade Systems for EGCG Delivery and Their Possible Mechanisms of Action}

Food-grade encapsulation systems are considered to be an innovative strategy to improve the bioavailability of EGCG for oral administration. Simulated in vitro digestion models are usually used to evaluate the bioavailability of EGCG. In vitro modeling systems of oral phase, gastric phase, small intestine and colon can be simulated. EGCG released from encapsulated materials under GI conditions generally occurs through diffusion and destruction of the particles by digestion. Digestive enzymes play a vital role in EGCG oral delivery because EGCG could interact with salivary proteins and inhibit lipase and protease activity $[83,84]$. EGCG release in in vitro digestion systems after encapsulation is presented in Table 4.

The protective effects of EGCG encapsulated by food grade materials were systematically investigated. Sodium caseinate emulsions loaded with EGCG were subjected to three stages of in vitro digestion, in which extensive physical changes were induced by saliva components and fatty acid release was reduced in the duodenal stage [46]. $\beta$-LG-EGCG complex showed relatively faster EGCG release rates compared with $\beta$-LG complex with chitosan or chlorogenic acid. Chitosan/ $\beta$-LG double walled structures improved the controlled release of EGCG because $\beta$-LG was resistant to proteolysis of pepsin and could be easily hydrolyzed by trypsin in neutral aqueous solution [49]. After the degradation of $\beta$-LG, the exposed chitosan can adhere to the intestinal wall to increase the residence time of EGCG in the intestinal tract, resulting in improved bioavailability [49]. $\beta$-LG-CA conjugate showed slow release rate and extent of EGCG through inhibiting the activity of digestive enzymes [50]. Delivering EGCG by zein and sodium caseinate tunes the release of EGCG by forming a coating layer during digestion, and encapsulating EGCG to zein-based system modulates the rate of fat digestion via Pickering emulsion stabilization effect and interaction between EGCG and lipase enzyme [56]. EGCG encapsulated by proteins inhibited the activity of lipase, and it has been suggested that EGCG reduce adipose tissue mass via lipase inhibitory effects [85]. 
Table 4. EGCG release in vitro digestion system after encapsulation.

\begin{tabular}{|c|c|c|c|}
\hline Encapsulation System & In Vitro Digestion System & EGCG Release in Vitro Digestion & Reference \\
\hline$\beta$-LG; Chitosan & $\begin{array}{l}\text { GP: pH } 2.0 \\
\text { IP: pH } 6.8\end{array}$ & $\begin{array}{l}\text { GP: } \%(t): \sim 30 \%(2 h) \\
\text { IP:\% (t): } \sim 70 \%(4 \mathrm{~h})\end{array}$ & Liang et al., 2016 [49] \\
\hline$\beta$-LG-chlorogenic acid & $\begin{array}{l}\text { GP: pH } 1.5 \\
\text { IP: pH } 6.5\end{array}$ & $\begin{array}{l}\text { GP: } \%(t): 14.2 \%(3 \mathrm{~h}) \\
\text { IP: } \%(\mathrm{t}): 32.7 \%(4 \mathrm{~h})\end{array}$ & Fan et al., 2017 [50] \\
\hline Gelatin & $\begin{array}{l}\text { GP: pH } 3 \\
\text { IP: pH } 7\end{array}$ & $\begin{array}{l}\text { GP: RSA } \%(\mathrm{t}): 23 \%(2 \mathrm{~h}) \\
\text { IP: RSA } \%(\mathrm{t}): 36 \%(2 \mathrm{~h})\end{array}$ & $\begin{array}{l}\text { Gomez-Mascaraqueet al., } \\
\text { 2016. [55] }\end{array}$ \\
\hline Chitosan & $\begin{array}{l}\text { GP: pH } 3 \\
\text { IP: pH } 7\end{array}$ & $\begin{array}{l}\text { GP: RSA } \%(\mathrm{t}): 15 \%(2 \mathrm{~h}) \\
\text { IP: RSA } \%(\mathrm{t}): 5 \%(2 \mathrm{~h})\end{array}$ & $\begin{array}{l}\text { Gomez-Mascaraque et al., } \\
\text { 2016. [55] }\end{array}$ \\
\hline Zein; sodium caseinate & $\begin{array}{l}\text { GP: pH } 1.2 \\
\text { IP: pH } 7.4\end{array}$ & $\begin{array}{l}\text { GP: \% (t): } \sim 90 \%(2 \mathrm{~h}) \\
\text { IP: \% (t): } \sim 90 \%(2 \mathrm{~h})\end{array}$ & Donsi et al., 2017 [56] \\
\hline $\begin{array}{l}\text { Amphiphilic chitosan; } \\
\text { dextran sulfate; cholesterol }\end{array}$ & IP: pH 7.4 & $\begin{array}{l}\text { IP: \% (t): 63\%(2 h) } \\
51 \%(3 \mathrm{~h})\end{array}$ & Zou et al., 2015 [64] \\
\hline Chitosan; CPP & $\begin{array}{l}\text { GP: pH } 1.2 \\
\text { IP: pH } 7.4\end{array}$ & $\begin{array}{l}\text { GP: } \%(t): ~ 45 \%(2 \sim 8 h) \\
\text { IP: \% (t): 35 40\% (2h) } \\
\text { 32 25\% (3 8 h) }\end{array}$ & Hu et al., 2015 [65] \\
\hline Chitosan; CPP; gallic acid & $\begin{array}{l}\text { GP: pH } 1.2 \\
\text { IP: pH } 7.4\end{array}$ & $\begin{array}{l}\text { GP: } \%(\mathrm{t}): \sim 40 \%(2 \sim 8 \mathrm{~h}) \\
\text { IP: } \%(\mathrm{t}): 35 \sim 40 \%(2 \mathrm{~h}) \\
32 \sim 25 \%(3 \sim 8 \mathrm{~h})\end{array}$ & Hu et al., 2015 [65] \\
\hline Chitosan; CPP & GP: pH 1.2 & $\begin{array}{l}\text { GP: } \%(\mathrm{t}): \sim 35 \%(2 \mathrm{~h}) \\
\sim 40 \%(4-8 \mathrm{~h})\end{array}$ & Hu et al., 2016 [72] \\
\hline Chitosan; CPP; caffeic acid & GP: pH 1.2 & $\begin{array}{l}\text { GP: \% (t): 25\% (2 h) } \\
\sim 30 \%(4-8 \mathrm{~h})\end{array}$ & Hu et al., 2016 [72] \\
\hline Chitosan; CPP; ferulic acid & GP: pH 1.2 & $\begin{array}{l}\text { GP: \% (t): } \sim 30 \%(2 \mathrm{~h}) \\
\sim 35 \%(4-8 \mathrm{~h})\end{array}$ & Hu et al., 2016 [72] \\
\hline PC; cholesterol & $\begin{array}{l}\text { GP: pH } 1.3 \\
\text { IP: pH } 7.5\end{array}$ & $\begin{array}{l}\text { GP: } \%(t): 21 \%(4 h) \\
\text { IP: } \%(t): 35 \%(4 h)\end{array}$ & Luo et al., 2014 [74] \\
\hline Phospholipid; cholesterol & $\begin{array}{l}\text { GP: pH } 1.2 \\
\text { IP: pH } 7.4\end{array}$ & $\begin{array}{l}\text { GP: \% (t): } 94 \%(3 \mathrm{~h}) \\
\text { IP: } \%(\mathrm{t}): 94 \sim 7.8 \%(0 \sim 3 \mathrm{~h})\end{array}$ & Zou et al., 2014 [75] \\
\hline Cholesterol & $\begin{array}{l}\text { GP: pH } 2.0 \\
\text { IP: pH } 7.4\end{array}$ & $\begin{array}{l}\text { GP: \% (t): } 99 \%(1 \mathrm{~h}) \\
\text { IP: } \%(\mathrm{t}): 49 \%(2 \mathrm{~h})\end{array}$ & Liang et al., 2016 [76] \\
\hline NLC; folic acid & $\begin{array}{l}\text { GP: pH } 1.6 \\
\text { IP: pH } 6.5\end{array}$ & $\begin{array}{l}\text { GP: \% (t): } 13 \%(3 \mathrm{~h}) \\
\text { IP: \% (t): } 19 \sim 48 \%(3 \sim 21 \mathrm{~h})\end{array}$ & Granja et al., 2017 [81] \\
\hline
\end{tabular}

IC: Initial concentration of the encapsulated particle; RM: release media, \% (t): \% of EGCG released from total nominal EGCG in time $t$; RSA \% (t): \% of radical scavenging activity in time $t$; GP: gastric phase; IP: intestinal phase; CPP: caseinophosphopeptide; PC: phosphatidylcholine; NLC: nanostructured lipid carriers; /: no data.

Chitosan is the only alkaline natural polysaccharide, which possesses positive charge and therefore binds strongly to negatively charged surfaces. Chitosan has many biological functions and it was widely used in preparing EGCG encapsulates with unique properties, such as controlled release, mucoadhesion, permeation enhancing, and efflux pump inhibitory effects. It is documented that chitosan can penetrate across the small intestinal epithelium in two ways, i.e., transcellular and paracellular pathways [86]. Encapsulation of EGCG with dextran sulfate-coated amphiphilic chitosan derivative-based nanoliposomes showed a stabilizing effect on the EGCG. The residual EGCG was $69.6 \%$ and $51.1 \%$ after $1.5 \mathrm{~h}$ and $3 \mathrm{~h}$, respectively, which indicated a significantly reduced degradation of EGCG in simulated intestinal fluid, showing stability-enhancing ability [64]. It was also reported that chitosan can enhance the plasma exposure of EGCG through an enhancement in concentrations of EGCG in the stomach and jejunum of mice [87]. Nanoparticles fabricated by chitosan and CPP enhanced the intestinal permeation of EGCG through Caco-2 cells model with a maximum $P_{\text {app }}$ value $1.3 \times 10^{-6} \mathrm{~cm} / \mathrm{s}$, which was significantly higher than the maximum $\mathrm{P}_{\text {app }}$ by non-encapsulated EGCG $\left(3.5 \times 10^{-7} \mathrm{~cm} / \mathrm{s}\right)$ [67]. The increased penetration may be contributed by the opening of the cellular tight junction and the enhancement of intracellular transportation. It is shown that chitosan carriers can inhibit intestinal P-gp and improve the adsorption of bioactives [88]. The possible interactions between polymeric efflux pump inhibitors (like chitosan) and efflux pumps as follows: (a) inhibition mediated by ATP depletion, (b) inhibition mediated by interaction with the membrane, (c) bypassing 
bioactive efflux by a drug-polymer conjugate, (d) inhibition mediated by interfering with ATP-binding sites and, (e) blocking of drug binding sites or other sites within the trans-membrane domains [89]. EGCG-loaded chitosan-CPP nanoparticles could enter Caco-2 cells in dose and time dependent manner, and the intestinal permeability and absorption of EGCG were significantly enhanced as delivered by chitosan [90].

EGCG nanoliposomes and niosomes were used to overcome the chemical instability of EGCG and enhance its bioavailability. EGCG encapsulated in lipids was isolated from the external membrane environment by a lipid bilayer to decrease the environmental effects, such as oxygen level. In simulated intestinal fluid (SIF), the stability of EGCG was significantly improved by nanoliposome encapsulation. After $2 \mathrm{~h}$ of incubation, the residual EGCG encapsulated in nanoliposomes was $22.5 \%$ while non-encapsulated EGCG was not detected [75]. To improve the delivery efficiency of EGCG, nanoparticles can be coated with ligands such as folic acid to target the intestinal epithelial cells, with a $10 \%$ initial burst release in the first hours [81], and after $21 \mathrm{~h}$, the maximum cumulative release of EGCG is $48 \%$ [81], suggesting the lipids are suitable encapsulation materials for EGCG, protecting it from degradation by harsh intestinal conditions and enhancing its bioavailability. EGCG-SLN enhanced the permeation and retention effect in cancer cells, which improved the anticancer activity compared to free EGCG [76]. Lipids encapsulated EGCG is gradually released under harsh conditions, which can be directly taken up by epithelial cells in the small intestine [91], resulting in improvement of EGCG bioavailability. The effects of encapsulation on improvement of EGCG stability and bioavailability are shown in Figure 2.

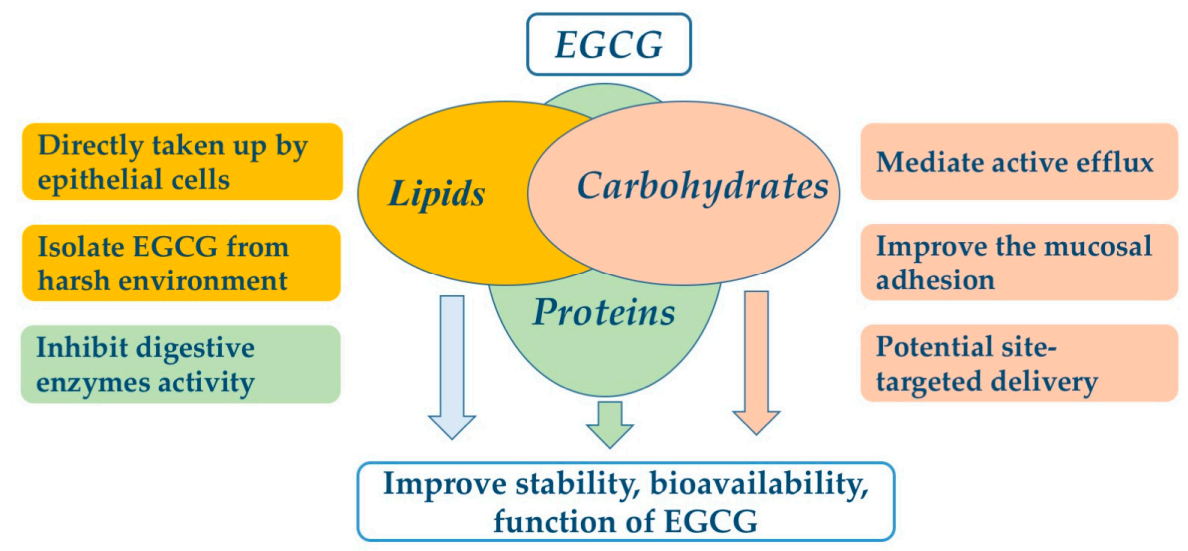

Figure 2. The potential mechanisms of food-grade encapsulate for improving EGCG bioavailability.

\section{Challenges}

Despite marked advantages, inconsistency between the research work and industry application is observed in food grade delivery systems. There are many factors leading to this inconsistency. First, the number of studies on the loading efficiencies is limited. Only a few studies have presented the loading efficiencies, which range from $0.37 \%$ to $30 \%[50,52,62,68,80,82]$. Second, it is difficult to compare the release of EGCG in different encapsulation systems owing to the differences in tested indicators of the different tests. There is no standard in vitro modeling method because the conditions involved in human digestion are complex and not completely elucidated yet [92]. There is a great difference in $\mathrm{pH}$ values in the reported in vitro intestinal digestion tests (Table 4). Third, there are many factors that influence the instability EGCG such as GI tract environmental conditions including $\mathrm{pH}$, ion levels and enzymes, which affect the efficiency of EGCG delivery. The $\mathrm{pH}$ is a crucial factor, and it influences not only the stability of EGCG, but also the encapsulation. The particle size of sodium caseinate emulsions loaded with EGCG showed a decreased extent of flocculation at $\mathrm{pH} 5$ compared with neutral pH [46]. During simulated intestinal digestion, the average diameter of EGCG-loaded niosomes increased from $60 \mathrm{~nm}$ to $178 \mathrm{~nm}$ in $2 \mathrm{~h}$ [76]. Nanoparticles formed by EGCG and chitosan 
showed a rapid increase in particle size from 103 to $856 \mathrm{~nm}$ when the $\mathrm{pH}$ value was increased from $\mathrm{pH} 3.5$ to $\mathrm{pH} 7.4$ [63]. Digestive enzyme, mucin and ions are also important factors inducing the aggregation during in vitro oral processing $[46,49,76]$. Finally, the effect of encapsulated EGCG should finally be confirmed by clinic studies. Oral administration of $400 \mathrm{~mL}$ of $1.25 \%$ green tea $(134 \mathrm{mg}$ of EGCG in total) by adults, the plasma EGCG concentration was about $80 \mathrm{nmol} / \mathrm{L}$ during a period up to $12 \mathrm{~h}$ after administration [93], which was much lower than the $50 \%$ inhibition concentration $\left(\mathrm{IC}_{50}\right)$ of EGCG against $\alpha$-amylase (about $52 \mu \mathrm{mol} / \mathrm{L}$ ) [93] and against proliferation of HCT116 colon cancer cells $(145 \mu \mathrm{mol} / \mathrm{L})$ [94]. When male Swiss Outbred mice were orally administered EGCG encapsulated in chitosan nanoparticles $(0.76 \mathrm{mg} / \mathrm{kg}$, equating to $45.6 \mathrm{mg}$ per $60 \mathrm{~kg}$ adult animal), the plasma EGCG concentration was $37.8 \mathrm{nmol} / \mathrm{L}$ after $1.5 \mathrm{~h}$ of administration [87], which was still far below the previous $\mathrm{IC}_{50}$ values.

\section{Conclusions and Expectations}

EGCG has been confirmed to have broad beneficial health activities in cell and animal models, indicating it is a promising functional foodstuff for supplementation. However, its sensitivity to diverse environments, poor stability in GI passive diffusion and active efflux are major factors leading to the low bioavailability of EGCG. The stability, bioavailability and function of EGCG can all be improved by encapsulation using food grade materials such as proteins, carbohydrates and lipids. EGCG can be encapsulated in proteins by emulsification, ionic gelation, freeze drying, electrospraying, self-assembly, layer-by-layer assembly, vacuum evaporation, precipitation and covalent grafting. EGCG encapsulated in proteins shows a sustained release due in part to the inhibition of the activity of digestive enzymes. EGCG can be encapsulated in carbohydrates by homogenization and spray drying, gas saturated solution dry, self-assembly and ionic gelation. The EGCG incorporated into carbohydrates showed improved mucoadhesion, intestinal permeation, site-targeting delivery and inhibition of active efflux. EGCG can be encapsulated in lipids as SLN or NLC via homogenization, organic solvent evaporation and dynamic high-pressure microfluidization. The EGCG encapsulated in lipids showed improved stability and sustained release, and it can be directly taken up by epithelial cells. The loading efficiency in the encapsulating systems remains to be improved, and future work should be focused on the improvement of loading efficiencies in various materials, and the development of new materials to be used to stabilize EGCG during storage and enhance EGCG site-controlled release. Moreover, clinical translation of the encapsulated EGCG should be investigated and the related mechanisms should be theoretically demonstrated. Overall, encapsulating EGCG with food grade materials could improve the bioavailability and functionality of EGCG, which have the potential to be wildly applied in functional foodstuff sector.

Acknowledgments: This work was financially supported by the Specialized Research Fund for the Doctoral Program of Higher Education of China (SRFDP No.20110101110094). We wish to express our sincerest thanks to Curt A.P. for his kind English revision and grammar corrections.

Author Contributions: M.S.: literature search, Section 3.1. Proteins for EGCG encapsulation; Y.-L.S.: 2. EGCG in tea; X.M.L.: 1. Introduction; R.Y.: 3.2. Carbohydrates for EGCG microencapsulation; Z.Y.C. \& Q.S.L.: 3.3. Lipids for EGCG microencapsulation; S.C.M. \& J.H.Y.: 3.4. Food grade systems for EGCG delivery and their possible mechanisms; J.L.L.: Figures 1 and 2; Y.R.L.: Project design, outline and 4. Challenges; X.Q.Z.: 5. Conclusions and expectations, Abstract, Final approval of the version to be published.

Conflicts of Interest: The authors declare no conflict of interest.

\section{References}

1. Fu, Q.Y.; Li, Q.S.; Lin, X.M.; Qiao, R.Y.; Yang, R.; Li, X.M.; Dong, Z.B.; Xiang, L.P.; Zheng, X.Q.; Lu, J.L.; et al. Antidiabetic effects of tea. Molecules 2017, 22, 849. [CrossRef] [PubMed]

2. Thitimuta, S.; Pithayanukul, P.; Nithitanakool, S.; Bavovada, R.; Leanpolchareanchai, J.; Saparpakorn, P. Camellia sinensis 1. Extract and its potential beneficial effects in antioxidant, anti-inflammatory, anti-hepatotoxic, and anti-tyrosinase activities. Molecules 2017, 22, 401. [CrossRef] [PubMed] 
3. Kondo, K.; Kurihara, M.; Miyata, N.; Suzuki, T.; Toyoda, M. Mechanistic studies of catechins as antioxidants against radical oxidation. Arch. Biochem. Biophys. 1999, 362, 79-86. [CrossRef] [PubMed]

4. Xiang, L.P.; Wang, A.; Ye, J.H.; Zheng, X.Q.; Polito, C.A.; Lu, J.L.; Li, Q.S.; Liang, Y.R. Suppressive effects of tea catechins on breast cancer. Nutrients 2016, 8, 458. [CrossRef] [PubMed]

5. Du, L.L.; Fu, Q.Y.; Xiang, L.P.; Zheng, X.Q.; Lu, J.L.; Ye, J.H.; Li, Q.S.; Polito, C.A.; Liang, Y.R. Tea polysaccharides and their bioactivities. Molecules 2016, 21, 1449. [CrossRef] [PubMed]

6. Shi, M.; Nie, Y.; Zheng, X.Q.; Lu, J.L.; Liang, Y.R.; Ye, J.H. Ultraviolet b (uvb) photosensitivities of tea catechins and the relevant chemical conversions. Molecules 2016, 21, 1345. [CrossRef] [PubMed]

7. Liu, C.; Zheng, X.Q.; Xiang, L.P.; Lu, J.L.; Polito, C.A.; Liang, Y.R. Protective effect of (-)-epigallocatechin gallate on ultraviolet b-induced skin damage in hairless mice. Trop. J. Pharm. Res. 2016, 15, 1183-1189. [CrossRef]

8. Nagle, D.G.; Ferreira, D.; Zhou, Y.D. Epigallocatechin-3-gallate (egcg): Chemical and biomedical perspectives. Phytochemistry 2006, 67, 1849-1855. [CrossRef] [PubMed]

9. Krupkova, O.; Ferguson, S.J.; Wuertz-Kozak, K. Stability of (-)-epigallocatechin gallate and its activity in liquid formulations and delivery systems. J. Nutr. Biochem. 2016, 37, 1-12. [CrossRef] [PubMed]

10. Yang, C.S.; Sang, S.M.; Lambert, J.D.; Lee, M.J. Bioavailability issues in studying the health effects of plant polyphenolic compounds. Mol. Nutr. Food Res. 2008, 52, S139-S151. [CrossRef] [PubMed]

11. Lam, P.L.; Gambari, R. Advanced progress of microencapsulation technologies: In vivo and in vitro models for studying oral and transdermal drug deliveries. J. Control. Release 2014, 178, 25-45. [CrossRef] [PubMed]

12. Kuang, S.S.; Oliveira, J.C.; Crean, A.M. Microencapsulation as a tool for incorporating bioactive ingredients into food. Crit. Rev. Food Sci. 2010, 50, 951-968. [CrossRef] [PubMed]

13. Nesterenko, A.; Alric, I.; Silvestre, F.; Durrieu, V. Vegetable proteins in microencapsulation: A review of recent interventions and their effectiveness. Ind. Crops Prod. 2013, 42, 469-479. [CrossRef]

14. Higdon, J.V.; Frei, B. Tea catechins and polyphenols: Health effects, metabolism, and antioxidant functions. Crit. Rev. Food Sci. Nutr. 2003, 43, 89-143. [CrossRef] [PubMed]

15. Miketova, P.; Schram, K.H.; Whitney, J.; Li, M.; Huang, R.; Kerns, E.; Valcic, S.; Timmermann, B.N.; Rourick, R.; Klohr, S. Tandem mass spectrometry studies of green tea catechins. Identification of three minor components in the polyphenolic extract of green tea. J. Mass Spectrom. 2000, 35, 860-869. [CrossRef]

16. Cai, Y.; Zhang, J.; Chen, N.G.; Shi, Z.; Qiu, J.; He, C.; Chen, M. Recent advances in anticancer activities and drug delivery systems of tannins. Med. Res. Rev. 2017, 37, 665-701. [CrossRef] [PubMed]

17. Thangapandiyan, S.; Miltonprabu, S. Epigallocatechin gallate effectively ameliorates fluoride-induced oxidative stress and DNA damage in the liver of rats. Can. J. Physiol. Pharmacol. 2013, 91, 528-537. [CrossRef] [PubMed]

18. Babu, P.V.; Si, H.; Liu, D. Epigallocatechin gallate reduces vascular inflammation in db/db mice possibly through an nf-kappab-mediated mechanism. Mol. Nutr. Food Res. 2012, 56, 1424-1432. [CrossRef] [PubMed]

19. Tedeschi, E.; Suzuki, H.; Menegazzi, M. Antiinflammatory action of egcg, the main component of green tea, through stat-1 inhibition. Ann. N. Y. Acad. Sci. 2002, 973, 435-437. [CrossRef] [PubMed]

20. Valcic, S.; Muders, A.; Jacobsen, N.E.; Liebler, D.C.; Timmermann, B.N. Antioxidant chemistry of green tea catechins. Identification of products of the reaction of (-)-epigallocatechin gallate with peroxyl radicals. Chem. Res. Toxicol. 1999, 12, 382-386. [CrossRef] [PubMed]

21. Fujiki, H.; Yoshizawa, S.; Horiuchi, T.; Suganuma, M.; Yatsunami, J.; Nishiwaki, S.; Okabe, S.; Nishiwaki-Matsushima, R.; Okuda, T.; Sugimura, T. Anticarcinogenic effects of (-)-epigallocatechin gallate. Prev. Med. 1992, 21, 503-509. [CrossRef]

22. Li, N.; Taylor, L.S.; Ferruzzi, M.G.; Mauer, L.J. Kinetic study of catechin stability: Effects of ph, concentration, and temperature. J. Agric. Food Chem. 2012, 60, 12531-12539. [CrossRef] [PubMed]

23. Wang, R.; Zhou, W.B.; Wen, R.A.H. Kinetic study of the thermal stability of tea catechins in aqueous systems using a microwave reactor. J. Agric. Food Chem. 2006, 54, 5924-5932. [CrossRef] [PubMed]

24. Zhu, Q.Y.; Zhang, A.Q.; Tsang, D.; Huang, Y.; Chen, Z.Y. Stability of green tea catechins. J. Agric. Food Chem. 1997, 45, 4624-4628. [CrossRef]

25. Zeng, L.; Ma, M.J.; Li, C.; Luo, L.Y. Stability of tea polyphenols solution with different ph at different temperatures. Int. J. Food Prop. 2017, 20, 1-18. [CrossRef]

26. Fan, F.Y.; Shi, M.; Nie, Y.; Zhao, Y.; Ye, J.H.; Liang, Y.R. Differential behaviors of tea catechins under thermal processing: Formation of non-enzymatic oligomers. Food Chem. 2016, 196, 347-354. [CrossRef] [PubMed] 
27. Sang, S.M.; Lee, M.J.; Hou, Z.; Ho, C.T.; Yang, C.S. Stability of tea polyphenol (-)-epigallocatechin-3-gallate and formation of dimers and epimers under common experimental conditions. J. Agric. Food Chem. 2005, 53, 9478-9484. [CrossRef] [PubMed]

28. Wang, R.; Zhou, W.; Jiang, X. Reaction kinetics of degradation and epimerization of epigallocatechin gallate (egcg) in aqueous system over a wide temperature range. J. Agric. Food Chem. 2008, 56, 2694-2701. [CrossRef] [PubMed]

29. Suzuki, M.; Sano, M.; Yoshida, R.; Degawa, M.; Miyase, T.; Maeda-Yamamoto, M. Epimerization of tea catechins and o-methylated derivatives of (-)-epigallocatechin-3-o-gallate: Relationship between epimerization and chemical structure. J. Agric. Food Chem. 2003, 51, 510-514. [CrossRef] [PubMed]

30. Onoue, S.; Ochi, M.; Yamada, S. Development of (-)-epigallocatechin-3-gallate (egcg)-loaded enteric microparticles with intestinal mucoadhesive property. Int. J. Pharm. 2011, 410, 111-113. [CrossRef] [PubMed]

31. Green, R.J.; Murphy, A.S.; Schulz, B.; Watkins, B.A.; Ferruzzi, M.G. Common tea formulations modulate in vitro digestive recovery of green tea catechins. Mol. Nutr. Food Res. 2007, 51, 1152-1162. [CrossRef] [PubMed]

32. Krook, M.A.; Hagerman, A.E. Stability of polyphenols epigallocatechin gallate and pentagalloyl glucose in a simulated digestive system. Food Res. Int. 2012, 49, 112-116. [CrossRef] [PubMed]

33. Lambert, J.D.; Lee, M.J.; Diamond, L.; Ju, J.Y.; Bose, M.; Newmark, H.L.; Yang, C.S. Dose-dependent levels of epigallocatechin-3-gallate in human colon cancer cells and mouse plasma and tissues. Drug Metab. Dispos. 2006, 34, 8-11. [CrossRef] [PubMed]

34. Shi, M.; Huang, L.Y.; Nie, N.; Ye, J.H.; Zheng, X.Q.; Lu, J.L.; Liang, Y.R. Binding of tea catechins to rice bran protein isolate: Interaction and protective effect during in vitro digestion. Food Res. Int. 2017, 93, 1-7. [CrossRef] [PubMed]

35. Shim, S.M.; Yoo, S.H.; Ra, C.S.; Kim, Y.K.; Chung, J.O.; Lee, S.J. Digestive stability and absorption of green tea polyphenols: Influence of acid and xylitol addition. Food Res. Int. 2012, 45, 204-210. [CrossRef]

36. Xie, Y.L.; Kosinska, A.; Xu, H.R.; Andlauer, W. Milk enhances intestinal absorption of green tea catechins in in vitro digestion/caco-2 cells model. Food Res. Int. 2013, 53, 793-800. [CrossRef]

37. Zhang, L.; Chow, M.S.S.; Zuo, Z. Effect of the co-occurring components from green tea on the intestinal absorption and disposition of green tea polyphenols in caco-2 monolayer model. J. Pharm. Pharmacol. 2006, 58, 37-44. [CrossRef] [PubMed]

38. Chan, K.Y.; Zhang, L.; Zuo, Z. Intestinal efflux transport kinetics of green tea catechins in caco-2 monolayer model. J. Pharm. Pharmacol. 2007, 59, 395-400. [CrossRef] [PubMed]

39. Kadowaki, M.; Sugihara, N.; Tagashira, T.; Terao, K.; Furuno, K. Presence or absence of a gallate moiety on catechins affects their cellular transport. J. Pharm. Pharmacol. 2008, 60, 1189-1195. [CrossRef] [PubMed]

40. Hong, J.; Lu, H.; Meng, X.F.; Ryu, J.H.; Hara, Y.; Yang, C.S. Stability, cellular uptake, biotransformation, and efflux of tea polyphenol (-)-epigallocatechin-3-gallate in ht-29 human colon adenocarcinoma cells. Cancer Res. 2002, 62, 7241-7246. [PubMed]

41. Gao, S.; Hu, M. Bioavailability challenges associated with development of anti-cancer phenolics. Mini Rev. Med. Chem. 2010, 10, 550-567. [CrossRef] [PubMed]

42. Hong, J.; Lambert, J.D.; Lee, S.H.; Sinko, P.J.; Yang, C.S. Involvement of multidrug resistance-associated proteins in regulating cellular levels of (-)-epigallocatechin-3-gallate and its methyl metabolites. Biochem. Biophys. Res. Commun. 2003, 310, 222-227. [CrossRef] [PubMed]

43. Augustin, M.A.; Udabage, P. Influence of processing on functionality of milk and dairy proteins. Adv. Food Nutr. Res. 2007, 53, 1-38. [PubMed]

44. Sabouri, S.; Geng, J.H.; Corredig, M. Tea polyphenols association to caseinate-stabilized oil-water interfaces. Food Hydrocoll. 2015, 51, 95-100. [CrossRef]

45. Sabouri, S.; Corredig, M. Acid induced destabilization of emulsions prepared with sodium caseinate-epigallocatechin-gallate complexes. Food Hydrocoll. 2016, 61, 113-118. [CrossRef]

46. Sabouri, S.; Wright, A.J.; Corredig, M. In vitro digestion of sodium caseinate emulsions loaded with epigallocatechin gallate. Food Hydrocoll. 2017, 69, 350-358. [CrossRef]

47. Paximada, P.; Echegoyen, Y.; Koutinas, A.A.; Mandala, I.G.; Lagaron, J.M. Encapsulation of hydrophilic and lipophilized catechin into nanoparticles through emulsion electrospraying. Food Hydrocoll. 2017, 64, 123-132. [CrossRef] 
48. Ru, Q.M.; Yu, H.L.; Huang, Q.R. Encapsulation of epigallocatechin-3-gallate (egcg) using oil-in-water (o/w) submicrometer emulsions stabilized by iota-carrageenan and beta-lactoglobulin. J. Agric. Food Chem. 2010, 58, 10373-10381. [CrossRef] [PubMed]

49. Liang, J.; Yan, H.; Yang, H.J.; Kim, H.W.; Wan, X.C.; Lee, J.; Ko, S. Synthesis and controlled-release properties of chitosan/beta-lactoglobulin nanoparticles as carriers for oral administration of epigallocatechin gallate. Food Sci. Biotechnol. 2016, 25, 1583-1590. [CrossRef]

50. Fan, Y.T.; Zhang, Y.Z.; Yokoyama, W.; Yi, J. Beta-lactoglobulin-chlorogenic acid conjugate-based nanoparticles for delivery of (-)-epigallocatechin-3-gallate. RSC Adv. 2017, 7, 21366-21374. [CrossRef]

51. Shutava, T.G.; Balkundi, S.S.; Vangala, P.; Steffan, J.J.; Bigelow, R.L.; Cardelli, J.A.; O’Neal, D.P.; Lvov, Y.M. Layer-by-layer-coated gelatin nanoparticles as a vehicle for delivery of natural polyphenols. ACS Nano 2009, 3, 1877-1885. [CrossRef] [PubMed]

52. Shutava, T.G.; Balkundi, S.S.; Lvov, Y.M. (-)-epigallocatechin gallate/gelatin layer-by-layer assembled films and microcapsules. J. Colloid Interfaces Sci. 2009, 330, 276-283. [CrossRef] [PubMed]

53. Gomez-Mascaraque, L.G.; Lagaron, J.M.; Lopez-Rubio, A. Electrosprayed gelatin submicroparticles as edible carriers for the encapsulation of polyphenols of interest in functional foods. Food Hydrocoll. 2015, 49, 42-52. [CrossRef]

54. Garcia, J.P.D.; Hsieh, M.F.; Doma, B.T.; Peruelo, D.C.; Chen, I.H.; Lee, H.M. Synthesis of gelatin-gamma-polyglutamic acid-based hydrogel for the in vitro controlled release of epigallocatechin gallate (egcg) from camellia sinensis. Polymers 2014, 6, 39-58. [CrossRef]

55. Gomez-Mascaraque, L.G.; Soler, C.; Lopez-Rubio, A. Stability and bioaccessibility of egcg within edible micro-hydrogels. Chitosan vs. Gelatin, a comparative study. Food Hydrocoll. 2016, 61, 128-138. [CrossRef]

56. Donsi, F.; Voudouris, P.; Veen, S.J.; Velikov, K.P. Zein-based colloidal particles for encapsulation epigallocatechin gallate and delivery of epigallocatechin gallate. Food Hydrocoll. 2017, 63, 508-517. [CrossRef]

57. Liang, J.; Yan, H.; Wang, X.L.; Zhou, Y.B.; Gao, X.L.; Puligundla, P.; Wan, X.C. Encapsulation of epigallocatechin gallate in zein/chitosan nanoparticles for controlled applications in food systems. Food Chem. 2017, 231, 19-24. [CrossRef] [PubMed]

58. Yang, R.; Liu, Y.; Meng, D.; Chen, Z.; Blanchard, C.L.; Zhou, Z. Urea-driven epigallocatechin gallate (egcg) permeation into the ferritin cage, an innovative method for fabrication of protein-polyphenol co-assemblies. J. Agric. Food Chem. 2017, 65, 1410-1419. [CrossRef] [PubMed]

59. Peres, I.; Rocha, S.; Gomes, J.; Morais, S.; Pereira, M.C.; Coelho, M. Preservation of catechin antioxidant properties loaded in carbohydrate nanoparticles. Carbohyd. Polym. 2011, 86, 147-153. [CrossRef]

60. Rocha, S.; Generalov, R.; Pereira, M.D.; Peres, I.; Juzenas, P.; Coelho, M.A.N. Epigallocatechin gallate-loaded polysaccharide nanoparticles for prostate cancer chemoprevention. Nanomedicine 2011, 6, 79-87. [CrossRef] [PubMed]

61. Park, S.J.; Garcia, C.V.; Shin, G.H.; Kim, J.T. Fabrication and optimization of egcg-loaded nanoparticles by high pressure homogenization. J. Appl. Polym. Sci. 2016, 133. [CrossRef]

62. Goncalves, V.S.S.; Poejo, J.; Matias, A.A.; Rodriguez-Rojo, S.; Cocero, M.J.; Duarte, C.M.M. Using different natural origin carriers for development of epigallocatechin gallate (egcg) solid formulations with improved antioxidant activity by pgss-drying. RSC Adv. 2016, 6, 67599-67609. [CrossRef]

63. Hong, Z.Y.; Xu, Y.Q.; Yin, J.F.; Jin, J.C.; Jiang, Y.W.; Du, Q.Z. Improving the effectiveness of (-)-epigallocatechin gallate (egcg) against rabbit atherosclerosis by egcg-loaded nanoparticles prepared from chitosan and polyaspartic acid. J. Agric. Food Chem. 2014, 62, 12603-12609. [CrossRef] [PubMed]

64. Zou, L.Q.; Peng, S.F.; Liu, W.; Chen, X.; Liu, C.M. A novel delivery system dextran sulfate coated amphiphilic chitosan derivatives-based nanoliposome: Capacity to improve in vitro digestion stability of (-)-epigallocatechin gallate. Food Res. Int. 2015, 69, 114-120. [CrossRef]

65. Hu, B.; Wang, Y.; Xie, M.H.; Hu, G.L.; Ma, F.G.; Zeng, X.X. Polymer nanoparticles composed with gallic acid grafted chitosan and bioactive peptides combined antioxidant, anticancer activities and improved delivery property for labile polyphenols. J. Funct. Foods 2015, 15, 593-603. [CrossRef]

66. Hu, B.; Ting, Y.W.; Zeng, X.X.; Huang, Q.R. Bioactive peptides/chitosan nanoparticles enhance cellular antioxidant activity of (-)-epigallocatechin-3-gallate. J. Agric. Food Chem. 2013, 61, 875-881. [CrossRef] [PubMed] 
67. Hu, B.; Ting, Y.W.; Yang, X.Q.; Tang, W.P.; Zeng, X.X.; Huang, Q.R. Nanochemoprevention by encapsulation of (-)-epigallocatechin-3-gallate with bioactive peptides/chitosan nanoparticles for enhancement of its bioavailability. Chem. Commun. 2012, 48, 2421-2423. [CrossRef] [PubMed]

68. Dube, A.; Nicolazzo, J.A.; Larson, I. Chitosan nanoparticles enhance the intestinal absorption of the green tea catechins (+)-catechin and (-)-epigallocatechin gallate. Eur. J. Pharm. Sci. 2010, 41, 219-225. [CrossRef] [PubMed]

69. Liu, F.; Majeed, H.; Antoniou, J.; Li, Y.; Ma, Y.; Yokoyama, W.; Ma, J.G.; Zhong, F. Ph and temperature stability of (-)-epigallocatechin-3-gallate-beta-cyclodextrin inclusion complex-loaded chitosan nanoparticles. Carbohyd. Polym. 2016, 149, 340-347. [CrossRef] [PubMed]

70. Liang, J.; Cao, L.; Zhang, L.; Wan, X.C. Preparation, characterization, and in vitro antitumor activity of folate conjugated chitosan coated egcg nanoparticles. Food Sci. Biotechnol. 2014, 23, 569-575. [CrossRef]

71. Jang, K.I.; Lee, H.G. Stability of chitosan nanoparticles for 1-ascorbic acid during heat treatment in aqueous solution. J. Agric. Food Chem. 2008, 56, 1936-1941. [CrossRef] [PubMed]

72. Hu, B.; Ma, F.G.; Yang, Y.K.; Xie, M.H.; Zhang, C.; Xu, Y.; Zeng, X.X. Antioxidant nanocomplexes for delivery of epigallocatechin-3-gallate. J. Agric. Food Chem. 2016, 64, 3422-3429. [CrossRef] [PubMed]

73. Fang, J.Y.; Lee, W.R.; Shen, S.C.; Huang, Y.L. Effect of liposome encapsulation of tea catechins on their accumulation in basal cell carcinomas. J. Dermatol. Sci. 2006, 42, 101-109. [CrossRef] [PubMed]

74. Luo, X.; Guan, R.; Chen, X.; Tao, M.; Ma, J.; Zhao, J. Optimization on condition of epigallocatechin-3-gallate (egcg) nanoliposomes by response surface methodology and cellular uptake studies in caco-2 cells. Nanoscale Res. Lett. 2014, 9, 291. [CrossRef] [PubMed]

75. Zou, L.Q.; Peng, S.F.; Liu, W.; Gan, L.; Liu, W.L.; Liang, R.H.; Liu, C.M.; Niu, J.; Cao, Y.L.; Liu, Z.; et al. Improved in vitro digestion stability of (-)-epigallocatechin gallate through nanoliposome encapsulation. Food Res. Int. 2014, 64, 492-499. [CrossRef]

76. Liang, R.; Chen, L.; Yokoyama, W.; Williams, P.A.; Zhong, F. Niosomes consisting of tween-60 and cholesterol improve the chemical stability and antioxidant activity of (-)-epigallocatechin gallate under intestinal tract conditions. J. Agric. Food Chem. 2016, 64, 9180-9188. [CrossRef] [PubMed]

77. Rashidinejad, A.; Birch, E.J.; Sun-Waterhouse, D.; Everett, D.W. Effect of liposomal encapsulation on the recovery and antioxidant properties of green tea catechins incorporated into a hard low-fat cheese following in vitro simulated gastrointestinal digestion. Food Bioprod. Process. 2016, 100, 238-245. [CrossRef]

78. Rashidinejad, A.; Birch, E.J.; Sun-Waterhouse, D.; Everett, D.W. Delivery of green tea catechin and epigallocatechin gallate in liposomes incorporated into low-fat hard cheese. Food Chem. 2014, 156, 176-183. [CrossRef] [PubMed]

79. Radhakrishnan, R.; Kulhari, H.; Pooja, D.; Gudem, S.; Bhargava, S.; Shukla, R.; Sistla, R. Encapsulation of biophenolic phytochemical egcg within lipid nanoparticles enhances its stability and cytotoxicity against cancer. Chem. Phys. Lipids 2016, 198, 51-60. [CrossRef] [PubMed]

80. Istenic, K.; Korosec, R.C.; Ulrih, N.P. Encapsulation of (-)-epigallocatechin gallate into liposomes and into alginate or chitosan microparticles reinforced with liposomes. J. Sci. Food Agric. 2016, 96, 4623-4632. [CrossRef] [PubMed]

81. Granja, A.; Vieira, A.C.; Chaves, L.L.; Nunes, C.; Neves, A.R.; Pinheiro, M.; Reis, S. Folate-targeted nanostructured lipid carriers for enhanced oral delivery of epigallocatechin-3-gallate. Food Chem. 2017, 237, 803-810. [CrossRef] [PubMed]

82. Frias, I.; Neves, A.R.; Pinheiro, M.; Reis, S. Design, development, and characterization of lipid nanocarriers-based epigallocatechin gallate delivery system for preventive and therapeutic supplementation. Drug Des. Dev. Ther. 2016, 10, 3519-3528. [CrossRef] [PubMed]

83. Nakai, M.; Fukui, Y.; Asami, S.; Toyoda-Ono, Y.; Iwashita, T.; Shibata, H.; Mitsunaga, T.; Hashimoto, F.; Kiso, Y. Inhibitory effects of oolong tea polyphenols on pancreatic lipase in vitro. J. Agric. Food Chem. 2005, 53, 4593-4598. [CrossRef] [PubMed]

84. Rohn, S.; Rawel, H.M.; Kroll, J. Inhibitory effects of plant phenols on the activity of selected enzymes. J. Agric. Food Chem. 2002, 50, 3566-3571. [CrossRef]

85. Wolfram, S.; Raederstorff, D.; Wang, Y.; Teixeira, S.R.; Elste, V.; Weber, P. Teavigo (epigallocatechin gallate) supplementation prevents obesity in rodents by reducing adipose tissue mass. Ann. Nutr. Metab. 2005, 49, 54-63. [CrossRef] [PubMed] 
86. Liang, J.; Yan, H.; Puligundla, P.; Gao, X.L.; Zhou, Y.B.; Wan, X.C. Applications of chitosan nanoparticles to enhance absorption and bioavailability of tea polyphenols: A review. Food Hydrocoll. 2017, 69, 286-292. [CrossRef]

87. Dube, A.; Nicolazzo, J.A.; Larson, I. Chitosan nanoparticles enhance the plasma exposure of (-)-epigallocatechin gallate in mice through an enhancement in intestinal stability. Eur. J. Pharm. Sci. 2011, 44, 422-426. [CrossRef] [PubMed]

88. Mo, R.; Jin, X.; Li, N.; Ju, C.; Sun, M.; Zhang, C.; Ping, Q. The mechanism of enhancement on oral absorption of paclitaxel by n-octyl-o-sulfate chitosan micelles. Biomaterials 2011, 32, 4609-4620. [CrossRef] [PubMed]

89. Werle, M. Natural and synthetic polymers as inhibitors of drug efflux pumps. Pharm. Res. 2008, 25, 500-511. [CrossRef] [PubMed]

90. Hu, B.; Ting, Y.W.; Zeng, X.X.; Huang, Q.R. Cellular uptake and cytotoxicity of chitosan-caseinophosphopeptides nanocomplexes loaded with epigallocatechin gallate. Carbohyd. Polym. 2012, 89, 362-370. [CrossRef] [PubMed]

91. Hu, B.; Wang, S.S.; Li, J.; Zeng, X.X.; Huang, Q.R. Assembly of bioactive peptide-chitosan nanocomplexes. J. Phys. Chem. B 2011, 115, 7515-7523. [CrossRef] [PubMed]

92. Corstens, M.N.; Berton-Carabin, C.C.; de Vries, R.; Troost, F.J.; Masclee, A.A.M.; Schroen, K. Food-grade micro-encapsulation systems that may induce satiety via delayed lipolysis: A review. Crit. Rev. Food Sci. 2017, 57, 2218-2244. [CrossRef] [PubMed]

93. Renouf, M.; Guy, P.; Marmet, C.; Longet, K.; Fraering, A.L.; Moulin, J.; Barron, D.; Dionisi, F.; Cavin, C.; Steiling, H.; Williamson, G. Plasma appearance and correlation between coffee and green tea metabolites in human subjects. Br. J. Nutr. 2010, 104, 1635-1640. [CrossRef] [PubMed]

94. Henning, S.M.; Wang, P.W.; Abgaryan, N.; Vicinanza, R.; de Oliveira, D.M.; Zhang, Y.J.; Lee, R.P.; Carpenter, C.L.; Aronson, W.J.; Heber, D. Phenolic acid concentrations in plasma and urine from men consuming green or lack tea and potential chemopreventive properties for colon cancer. Mol. Nutr. Food Res. 2013, 57, 483-492. [CrossRef] [PubMed]

(C) 2018 by the authors. Licensee MDPI, Basel, Switzerland. This article is an open access article distributed under the terms and conditions of the Creative Commons Attribution (CC BY) license (http:/ / creativecommons.org/licenses/by/4.0/). 